\title{
Building the Rainbow Nation. A critical analysis of the role of architecture in materializing a post-apartheid South African identity
}

\author{
Kim De Raedt \\ Faculty of Engineering and Architecture, Ghent University, Belgium
}

\begin{abstract}
Soon after apartheid was abolished in 1994 , the quest for a new, 'authentic' South African identity resulted in the emergence of the "Rainbow Nation" idea, picturing an equal, multicultural and reconciled society. As architecture is considered a crucial element in the promotion of this Rainbow identity, the country witnessed a remarkable "building boom" with its apogee roughly between 1998 and 2010 . Huge investments have been made in state-driven projects which place the apartheid memory at the center of the architectural debate - mostly museums and memorials. However, the focus of this paper shall lie on another, less highlighted tendency in current architectural practice. This paper demonstrates that, through the construction of urban community services, South African architects attempt to materialize the Rainbow Nation in a way that might be closer to the everyday reality of society.
\end{abstract}

Key words: architecture, post apartheid, Cape Town, South Africa, identity

\section{Architecture and (Rainbow) Nation-Building}

"We have triumphed in the effort to implant hope in the breasts of the millions of our people. We enter into a covenant that we shall build the society in which all South Africans, both black and white, will be able to walk tall, without any fear in their hearts, assured of their inalienable right to human dignity a rainbow nation at peace with itself and the world."

Nelson Mandela ${ }^{1}$

With the official abolition of apartheid in 1994, the young South African democracy faced the daunting task of realizing, from the fragments of its pre- and postcolonial past, a new nation state possessing enough credibility to avoid falling victim to its own internal tensions. This soon gave rise to the idea of the Rainbow Nation, picturing a society characterized by equity, reconciliation and multiculturalism. This tremendous 
transformation did not, as in many other African countries a few decennia before, lead to an outburst of violence, or even a civil war. This was mainly due to the effort of the new government to promote 'reconciliation' and a national acceptance of diversity and multiculturality ${ }^{2}$. The shift to this new social paradigm implied a complete transformation, from a segregationist and racist society to a still-multiple but equal one, whose citizens are expected to assimilate an all inclusive 'Rainbow identity'3. Sabine Marschall believes the Rainbow Nation idea came to serve as the so-called 'foundation myth' which needed to be shared and internalized by as many South Africans as possible in order to obtain a unified society, a nation (Marschall, 2005). Such a nation, according to Benedict Anderson, is never the product of some kind of natural unity, but rather a fictitious political society. As the members of a nation can never continuously engage in face-to-face contact, the only awareness of the existence of a nation as one unified entity results from the 'image' they collectively have of it (Anderson, 1983). This image is developed and propagated via a strong and convincing representation of (new) power, and an emphasis on the collective acceptance of a (supposed) shared past. Almost thirty years ago, Pierre Nora elaborated on the various manifestations of this image of 'collectivesness', which he called lieux de mémoire, in the context of French nationalism. He defines these as "any significant entity, whether material or non-material in nature, which by dint of human will or the work of time has become a symbolic element of the memorial heritage of any community" (Lipstadt, I999: 243-45) ${ }^{4}$. As Nora explains, architecture is considered a crucial tool for nation buildings. It should not be surprising therefore that South Africa has witnessed a remarkable 'building boom' since the abolition of apartheid, with its apogee roughly between 1998 and 2010. With struggle and reconciliation at the core of the new national identity, massive investments were made, particularly in state-driven projects, which place the apartheid memory at the center of the architectural debate. The

A crucial instrument to achieve the restoration of human and civil dignity prescribed by the new constitutional law, was the so-called 'Truth and Reconciliation Commission' which, by promoting a national attitude of reconciliation towards the past and tolerance in the future, embodied the values inherent to Mandela's idea of a Rainbow Nation. This commission was charged with the revelation of gross violations of the human rights between I963 and 1993. By encouraging public testimony and dialogue, the TRC aimed to contribute to the achievement of national unity and peace in the country

On the subject of post-apartheid identity in South Africa see for example Distiller \& Steyn (2004), Doxtader \& Villa-Vicencio (2004), and Zegeye (2001).

Both conceptual entities like symbols, slogans and concepts, and concrete elements such as holidays, a flag, street names, monuments, buildings, landscapes and other 'places of memory' have, according to the author, made France what it is today, and are being used to keep the national collective memory alive for ensuing generations (on the subject of the relation between memory and nation-building see for example Graham \& Howard (2000), Evans \& Boswell (1999) and Barton (200I)). In the same way, renaming streets, introducing new holidays and designing a new flag were important strategies for the South African state to convincingly 'sell' the idea of the Rainbow Nation to its people and facilitate the internalization of the values it represents. Moreover, such activities are not only of a symbolic nature in South-Africa, but also reach into educational programs (school visits to sites of struggle and/or memorials, rituals, community-based information initiatives, etcetera).

5 An extensive body of literature has emerged in the last two or three decades showing how the manipulation of the built environment was crucial to the process of nation-building, especially in third world countries in the postcolonial period. See for example Vale (1992) and more recently Lu (20rI). 
results of this boom can be seen mainly in the form of museums and memorials inspired by both national and local culture and history ${ }^{6}$. As Lindsay Bremner explains "aside from being lucrative commissions for architects, these projects have received significant state funding to institutionalize and establish new histories of struggle. In so doing, architects have become agents in the re-imagining and representation of history." (Bremner, 2007: 85-103). The Apartheid Museum in Johannesburg (1999-2001), the Red Location Museum in Port Elizabeth (1998-2005-...) and the Gugulethu Seven Memorial in Cape Town (2004-2005) are but a few examples of projects where architecture very explicitly, but in a sense passively, contributes to the image of a new, unified South Africa. Indeed, rather than actively taking part in the transformation of the daily reality of society, they project a strong image embodying important national values.

However, we argue that a parallel, though less highlighted tendency of materializing the Rainbow Nation is made manifest through the transformation of the ordinary spaces of everyday reality. As Henri Lefebvre tellingly observed, "a revolution that does not produce a new space has not realized its full potential; indeed it has failed in that it has not changed life itself, but has merely changed ideological superstructures, institutions or political apparatuses. A social transformation, to be truly revolutionary in character, must manifest a creative capacity in its effects on daily life, on language and on space ..." (Lefebvre, I99I). In an article on spatial strategies used to achieve national integration in the formative years of the Turkish Republic, Zeynep Kezer points to the absence of this important aspect of nation-building in most of the studies relating nationhood and the built environment. She shows that by grounding the abstract concept of nationhood in concrete, real world experiences, 'ordinary places' such as parks, schools, hospitals and public works foster the feeling of a unified nation, socializing individuals into citizens, and uniting individual communities into one people (Kezer, 2009: 508-30). Contemporary publications on the architectural production in South Africa (see for example the architecture journals Digest of South African architecture and Architecture SA), indeed reveal an exponential increase in architectural typologies which reflect post-apartheid identity in an active way, contrary to the above mentioned memory projects. More specifically, through the construction of schools, markets, community centers and transport interchanges ${ }^{7}$ in urban areas (from this point onward these shall be referred to as 'urban community services') where any expenditure on public facilities was formerly absent, the country is materializing the social paradigms of the young Rainbow Nation in a way which is, as Kezer explains, much closer to the everyday reality of society. This implies that contemporary architects are expected to take position both against a very specific new set of programs and commissioners, and the ways in which these operate within social, economic, political, institutional and historical contexts.

Meanwhile, a critical questioning of the products of this parallel trend in architectural practice is still largely absent within the discipline. National publications such as

6 On the subject of the relation between visual culture and public memory in South Africa see for example Coombes (2003).

7 A transport interchange in South Africa is a transfer station between taxi, bus and train. 
those mentioned above choose mainly to engage in displaying the architectural production as such, introducing theoretical discourses (often written by the designers themselves) primarily to support the argument that the nation is successfully reconceptualizing itself through the built environment. Attempts at critical reflection upon architectural issues and opportunities arising from this reconceptualization seem to be made predominantly by white authors and often in cooperation with institutions based in Europe, for example the exhibition and book initiative Blank_Architecture, apartheid and after (Judin \& Vladislavić, 1998), and, more recently, the book Desire Lines: Space, Memory and Identity in the Post-Apartheid City (Hall et al., 2007). ${ }^{8}$

Overall, contributions critically questioning the role of architecture as a catalyst in the transformation of everyday reality from an explicitly architectural point of view appear to be rather scarce. This paper engages that space by taking the opportunity to focus specifically on the various ways in which architects are seeking the difficult and often fragile balance between architecture and politics. This quest forces them to examine the role of buildings in specific post-apartheid South African contexts, inevitably leading to discussions about the relation between architecture, appropriation and identity. However, ultimately, questions will arise about the extent to which architects are in fact capable of determining an unambiguous relation between their designs, how these are used and how they develop, and concepts such as social change and identity formation.

\section{Cape Town's Townships - Opportunities for relevances?}

Immediately following the abolition of apartheid, measures in the field of politics, culture and economics were taken to promote the development of a society in which op-

Judin, Hilton \& Vladislavić, Ivan (eds.) (1998). Blank_Architecture, apartheid and after. Rotterdam: NAi publishers. Hilton Judin is a South African architect, Ivan Vladislavic is a Croatian writer and editor currently living and working in Johannesburg. The initiative for the exhibition and the book was taken at the Nederlands Architectuurinstituut, a platform for discussion, project initiation and transfer of knowledge about architecture in Rotterdam, the Netherlands.

Hall, Martin \& Murray, Noëleen, Shepherd, Nick (eds.) (2007). Desire Lines - Space, memory and identity in the postapartheid city. New York: Routledge. The book appeared in the ArchiText series of Routledge, a publishing house based in the United Kingdom which chiefly produces academic books and journals. Nick Shepherd is a senior lecturer at the Centre for African Studies at UCT, and is also affiliated with the eponymous Centre at the University of Basel, Switzerland. Martin Hall is a British archeologist and anthropologist educated at the University of Cambridge, who currently holds a professorship at the University of Cape Town (UCT). Noëleen Murray is educated as an architect in South Africa and lectures at the Centre for African Studies at UCT.

Both publications address a wide spectrum of issues concerning the contemporary transformation of the built environment by presenting its readers interdisciplinary perspectives on architecture and urbanism. Blank should definitely be praised for its critical attitude towards all aspects of 'apartheid space' and the broadening of its context by including trans-disciplinary research. However, since the book's publication coincided with the beginning of large scale construction activity, it still focuses largely on 'Architecture, Apartheid' issues rather than engaging in a discussion on the 'and After' aspect. Desires Lines is an interesting complement in that sense, but nevertheless tends to focus mainly on the way in which a new identity is assumed through the assimilation of a national narrative based on apartheid memory.

9 "Opportunities for relevance: architecture in the new South Africa." is the title of a book by South African based Prof. Sabine Marschall and Brian Kearney, published in 2000. It presents new directions in South African architecture since 1994, showing how new approaches to design could provide opportunities for relevance today. 
portunities are equally distributed. Meanwhile, the built environment, shaped through decades of spatial segregation policy, turned out to be less susceptible to transformation. Since poor environments required spatial improvement to allow for economic, cultural and social development, and eventually the reconceptualization of personal and communal identities, initiatives were taken to invest in the (public) accommodation of poor urban areas (e.g. the Dignified Public Places program discussed below). Whereas in Johannesburg, the city center (the so-called CBD) had witnessed migrant flows to and from all over (South) Africa since the mid-eighties ${ }^{10}$, in Cape Town, employment and economic opportunities were less promising and the social geography of the city remained relatively untouched after apartheid. As such, the city center remained a relatively rich business enclave in the urban tissue, leaving the townships with a tremendous need of public expenditure. This neat and continuously maintained division between a small, well-functioning commercial enclave in the center and the vast, poorly equipped hinterland from which it is functionally almost completely separated, is exactly what makes Cape Town an interesting case for this study. Indeed, to become truly urban (after being excluded from the world economy for almost half a century) and thus realize the country's international aspirations, the City of Cape Town (CoCT) understood that it was essential to engage in the development of its poor suburbs. As a result, a strategy was put into effect which Teddy Cruz has called 'urban acupuncture': numerous projects for urban community services were commissioned by CoCT to be developed in the huge township 'belt' that borders the city center in the south-east.

\section{Materializing the Rainbow Nation - Shaping public space in Cape Town's townships}

To sketch the spectrum in which South African architects are operating and positioning themselves in Cape Town's contemporary reality, and to define its extremities, we will discuss two particular cases. One is a community center for Langa, the other a market infrastructure in Browns Farm (Figure $\mathrm{r}$ ). The discussion which follows is entirely based on conversations and discussions with architects and planners, users and managers of the buildings, all conducted in January 2010 during a research fieldtrip to Cape Town ${ }^{11}$.

It argues that architecture can play an important role both in dealing with the country's past as well as in reflecting transformations in society, and pleads explicitly for a uniquely South African architecture, to arise first and foremost from an embracement of its realities. However, although it uses abundant material to demonstrate the definition of relevant architecture by illustrating how design concepts lead to architectural shape, the authors do not study the implications of the architectural decisions as such.

10 These migrant flows were put in motion by the outflow of the rich top layer of the population (white and black alike) moving to the newly developing suburbia in the north of the city and thus transforming the original city centre in a 'poor urban area'. (See for example Bremner, Lindsay et.al. (eds.) (2003). Emerging Johannesburg: perspectives on the postapartheid city. London: Routledge, which focuses on the fragmentation and social polarisation of post-apartheid Johannesburg).

II This field trip was part of the research I did on the role of identity, memory and community in post-apartheid architecture practice in Cape Town, conducted in the framework of my master thesis in 2009-2010. Professor Johan Lagae and Professor Iain Low were respectively my promotor at the University of Ghent and local copromotor at the University of Cape Town. 


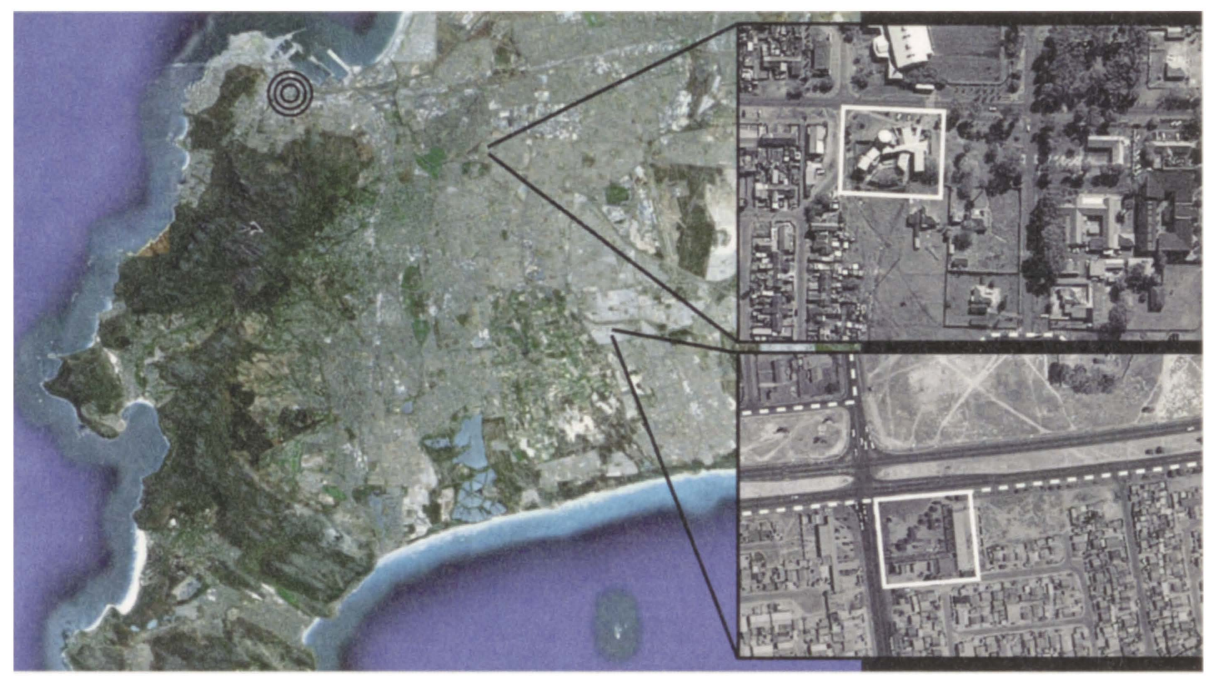

Figure 1: Satellite image of Cape Town with city center and location of two projects indicated (satellite images: Google Maps manipulated by the author)

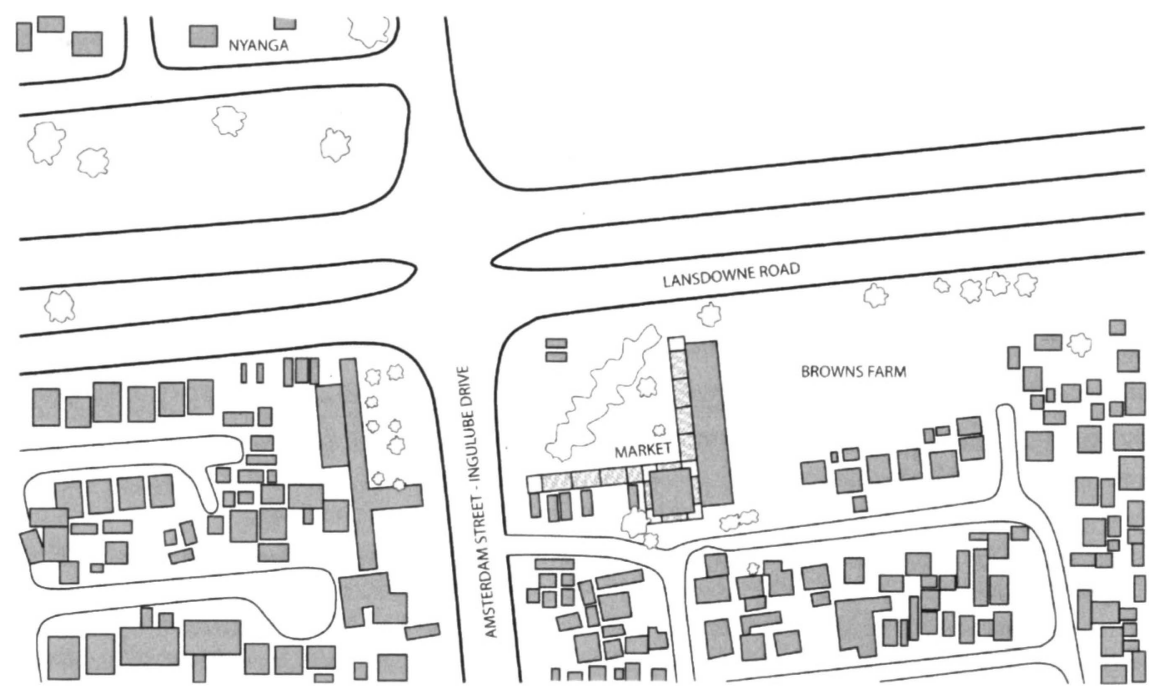

Figure 2: Site plan Browns Farm market with containers to the rear sides (schematic drawing by the author)

Du Toit \& Perrin Ass. \& Jacques Theron Ass._Market infrastructure in Browns Farm

Despite CoCT's ambition to improve the quality of the built environment in poor urban areas, public space lags behind the exponential construction rate of individual housing. Through initiatives like the Reconstruction and Development Programme 
(RDP) and the Integrated Service Land Project (ISLP) thousands of family dwellings are built each year. While much investment has been made in basic infrastructure, no statement has been made about public spaces in between the myriad rows of individual housing plots. Consequently, these new communities have gradually taken to the informal use of (unequipped) vacant space, in much the same way as townships established during apartheid exploited available space. This observation was the trigger for the CoCT to establish in 1999 the so-called Cape Town Municipal Spatial Development Framework (MSDF), aiming at wholesale urban transformation through the promotion of a greater sense of human dignity and equity. This aspiration was concretized by the 'Dignified Places Programme' (DPP), targeting the creation of meaningful public space through the implementation of (geographically and symbolically) strategic projects acting as catalysts for quick and positive urban development. The general idea was to harness the energy already present in certain public spaces and direct it towards the generation of public places where accessibility, human scale, flexibility of use, presence of public facilities and clear demarcation of the public space would be key concerns. To this end, "the programme has prioritized projects at stations and public transport interchanges, major pedestrian movement routes, at community facilities such as libraries, clinics and community centres and places that have a symbolic significance - sites of political struggle and special memory" (Southworth, 2005: 4-II). On such sites, basic low-cost infrastructure facilities would be developed that people could 'clip' onto. The projects therefore specifically focus on "those elements necessary for adequate definition, enclosure and identity such as paving, seating, trees, low walls and colonnades. (Southworth, 1999).

These intentions were quite literally translated by du Toit \& Perrin Ass., in association with Jacques Theron Ass., who were commissioned to make a design proposal for the formalization of informal trading activities on the corner of an intensively used crossroad in Browns Farm ${ }^{12}$. In the framework of the DPP philosophy, the new market infrastructure had to promote and stimulate public life on this crucial traffic node in the city, and as such become a catalyst for further social, economic and urban development. The project is situated on the corner of Ingulube Drive and Lansdowne Road, a major artery demarcating the border between Nyanga and Browns Farm, which connects the townships to the city center ${ }^{13}$. The DPP board suggested introducing a public market square focusing on a small informal economy as well as on pedestrian movement from the community to Lansdowne Road and Nyanga. The plan was to develop the four corners of the

The land was developed in the seventies, when townships closer to the city center (particularly Langa, Nyanga and Gugulethu) became overpopulated. Severe violence and political conflict pushed people out of these older settlements, forcing them towards so far undeveloped land in 'Die Duine'. This new community experienced dramatic growth over the next twenty years, again causing problematic criminality statistics. Early in 2000 it was finally decided to develop an ISLP (Integrated Service Land Project) for the area. In 2002, the informal settlement was entirely bulldozed and replaced by hundreds of small, identical 'formal' dwellings. The development and accommodation of public space was (and still is) not a priority. However, very soon the Browns Farm curse flared up again, when corruption in the ISLP project again resulted in alarming violence, still going on today. black and colored settlements remained manageable, enabling control over the community. 
crossroad, thus creating a kind of gateway into the city that would slow traffic and physically and mentally connect the surrounding settlements. To date, only the project we are discussing here and the one opposite Ingulube Drive have been realized.

As can be seen in Figure 2, du Toit, Perrin and Theron's building was eventually conceived as an L-shaped pergola structure in concrete, with an atrium in the knuckle ${ }^{14}$. This "urban infrastructure" was designed as a covered colonnade, a sequence of portico's of approximately 4 by 3.5 meter, that could be claimed by public functions (a minor clinic, a post office or a community center) or under which merchandise could be displayed. To the rear of the pergola, space was provided to place containers ${ }^{15}$ or any closed volume that would serve as fixed infrastructure plugged onto the building. The atrium in the knuckle was conceived as a public living room where washing facilities and public phones would be provided, and community meetings could take place. In time, successful operation of the project was expected to trigger the development of a second phase: physically, as the architects envisaged that shopkeepers would slowly start building individual dwellings on top of the structure thus creating a one story building, and mentally, as the gradual emergence of a public plaza through the further formalization and activation of its boundaries would stimulate a process of both personal and collective identity (re)construction in the community (Figure $3,4 \& 5)^{16}$.
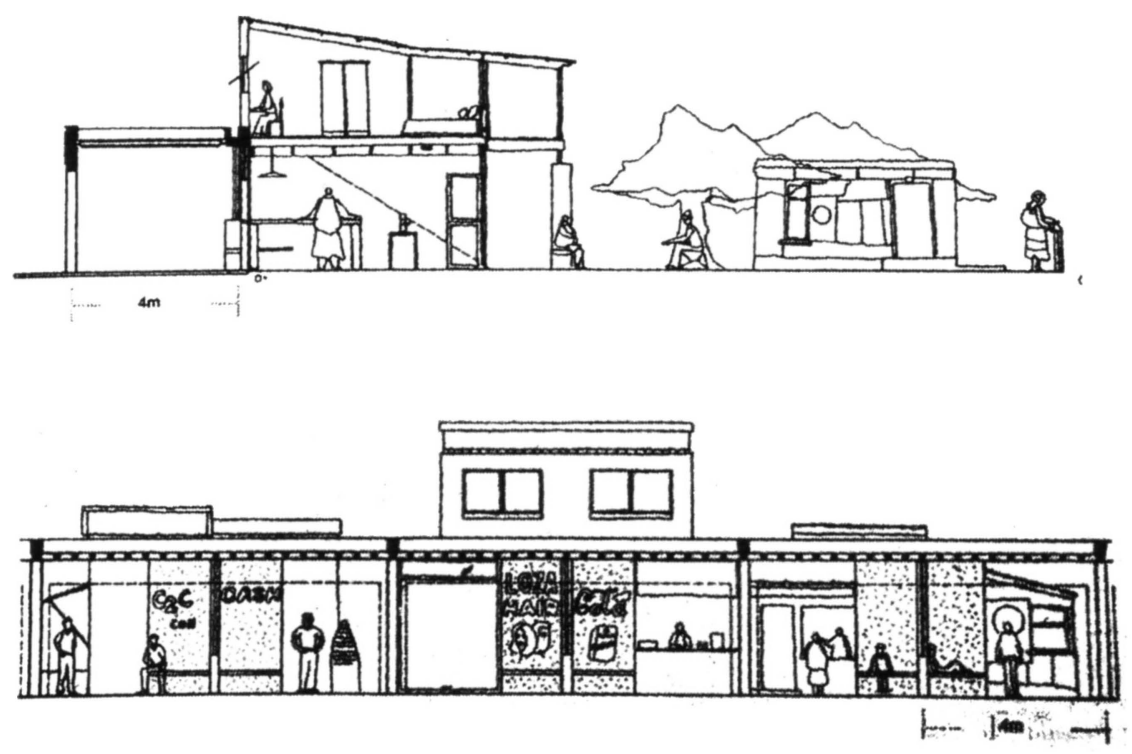

For the purpose of this paper the author developed schematic drawings of both projects based on a combination of drawings provided by the architects and Google maps, in order to obtain uniform drawing conventions necessary to assess both projects equally. 


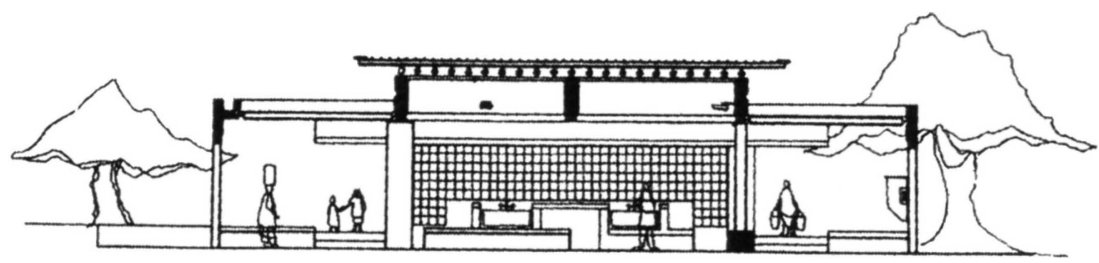

Figure 3, 4 \& 5: Drawings showing projected evolution of structure (Drawings: courtesy of the architect)

\section{CS Studio Architects Community Centre in Langa}

The Guga S'Thebe community center is located in Langa, one of the first 'model townships' east of Cape Town, developed in I923 to house black (mainly Xhosa speaking) South Africans ${ }^{17}$. In 1996 , the project was identified through a needs assessment by the Langa community - in the form of the "Langa Development Forum, Arts and Culture Environment and Tourism committee". Ultimately, CS Studio Architects, led by award winning architect Carin Smuts ${ }^{18}$, was approached to make a design for a community center where knowledge about arts and crafts could be practiced and transmitted. The project was envisaged within the framework of a wider initiative to develop a 'cultural precinct' that would contain the railway to the north and Maragana Square on the east side of the site $^{19}$. The community center would thus become part of the Guga S'Thebe Arts, Culture and Heritage Park - extending from Washington Street to the hostels in the south - which aspired to become an important tourist attraction in Cape Town. The community chose to name the building 'Guga S'Thebe', an expression derived from an old Xhosa idiom referring to an old (Guga) platter (S'Thebe) that has been in the family for a very long time. Everyone welcomed in the house is served with the platter, which thus has been passed onto people from many different generations and walks of life. As a true 'Guga S'Thebe', the center was to serve as a catalyst for the positive development of the community.

17 Langa, Xhosa for 'sun', is a typical product of the urban planning policy based on social segregation. It was developed in 1923 in the east of Cape Town to house black South-Africans outside the city centre, long before apartheid was officially institutionalized. Although it was idyllically presented as a kind of 'Garden City', the area has only one access road to facilitate control of the population, and the typical hostel structures for the so-called 'migrant workers' are still present and in use today. As one of the oldest black suburbs in Cape Town, Langa became an important place of resistance against the apartheid regime during the second half of the twentieth century. Today it has a very lively community, but with a huge unemployment rate. Only $40 \%$ of the working population has a fixed, contractual job, most others work in the informal economy.

18 Carin Smuts received the Global Award Sustainable Architecture in 2008. The prize honors architects whose work in their home-country focuses on sustainable development in all its aspects, whether it is North or South of the equator.

I9 Maragana Square is an important place of apartheid memory because in the sixties it was the place where people burnt their so-called pass-books (identification documents non white-people were obliged to carry to allow permanent identity control). 
In contrast to the restrained architectural language applied by du Toit, Perrin \& Theron, Smuts' response to the commission is a design that strongly focuses on the use of historic as well as symbolic metaphors, and at the same time refers intensively to specific features of township spatiality. The building comprises of five volumes in an asymmetrical constellation, whose shape and orientation are determined by the presence of a number of so-called 'desire lines' that arose on the site through the years, thus intending to embed the building in terms of space as well as time. Located behind a 'garden wall', the building can be entered via a forecourt, behind which the different volumes are organized around a central core in which the interior entrance space is located (Figure 6). According to the architect, this arrangement refers to an African conception of space in which a loose assembly of building modules generate a kind of semi-public interior/ exterior space, thus creating a 'village-like' organization in which the 'space-in-between' is as important as the inside space. According to the designers, such a lay-out is opposed to a European model, where building volumes are organized in a linear way. Whereas the majority of the volumes serve as workshops for different arts and crafts as well as administrative functions, the dominant structure, a golden cone, functions as a multifunctional space for visual arts and performance. It is thus presented as the ultimate materialization of the $\mathrm{S}^{\prime}$ Thebe (platter) metaphor. Formally it is meant to symbolize the 'rondawel', the traditional round hut which, according to chief architect Carin Smuts, the community wanted to be integrated as it supposedly refers to the dominant cultural and historical background of Langa. Additionally it functions as a landmark in the environment due to Langa, Xhosa for 'sun', is a typical product of the urban planning policy based on social segregation. It was developed in 1923 in the east of Cape Town to house black SouthAfricans outside the city centre, long before apartheid was officially institutionalized. Although it was idyllically presented as a kind of 'Garden City', the area has only one access road to facilitate control of the population, and the typical hostel structures for the so-called 'migrant workers' are still present and in use today. As one of the oldest black suburbs in Cape Town, Langa became an important place of resistance against the apartheid regime during the second half of the twentieth century. Today it has a very lively community, but with a huge unemployment rate. Only $40 \%$ of the working population has a fixed, contractual job, most others work in the informal economy. its remarkable shape and color. 


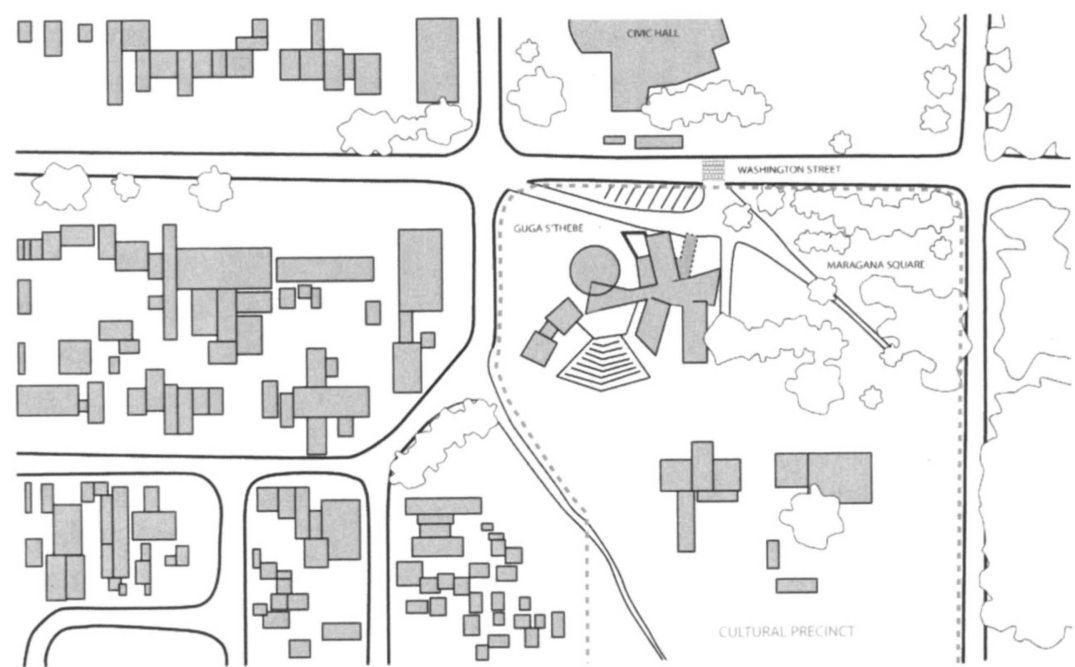

Figure 6: Site plan Guga s' Thebe Community Centre (schematic drawings by the author)

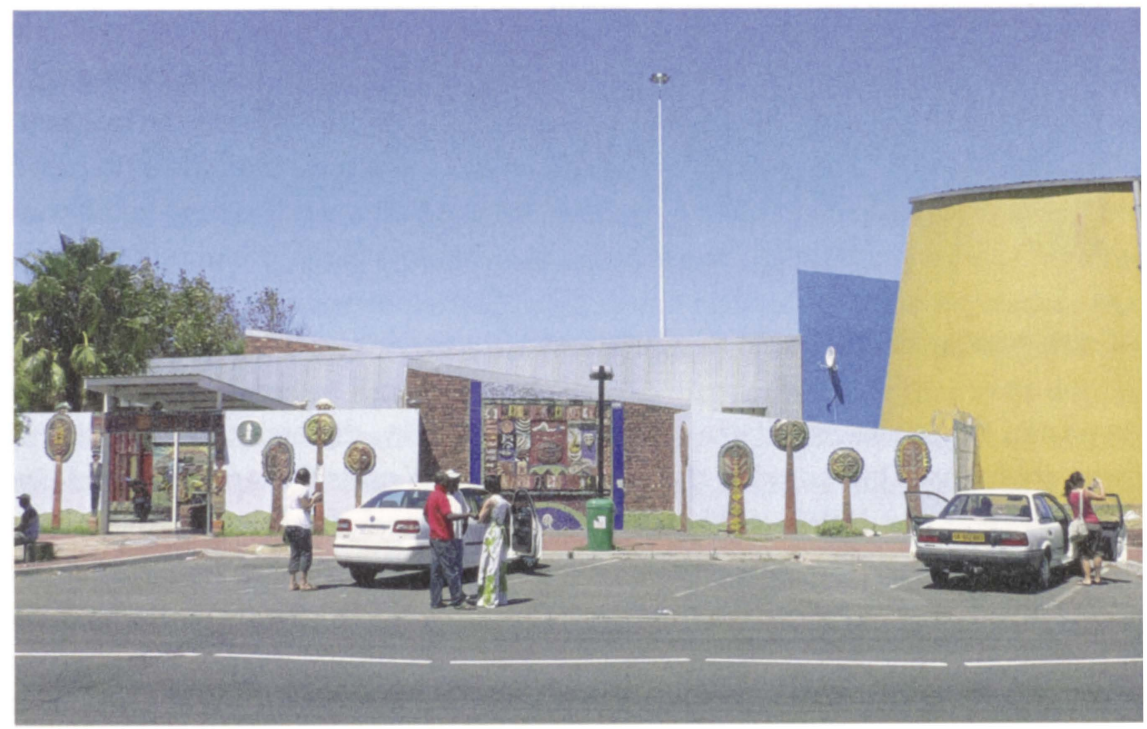

Figure 7: Ceramic mosaics on the "garden wall" and in the semi-public forecourt (photographs by the author) 


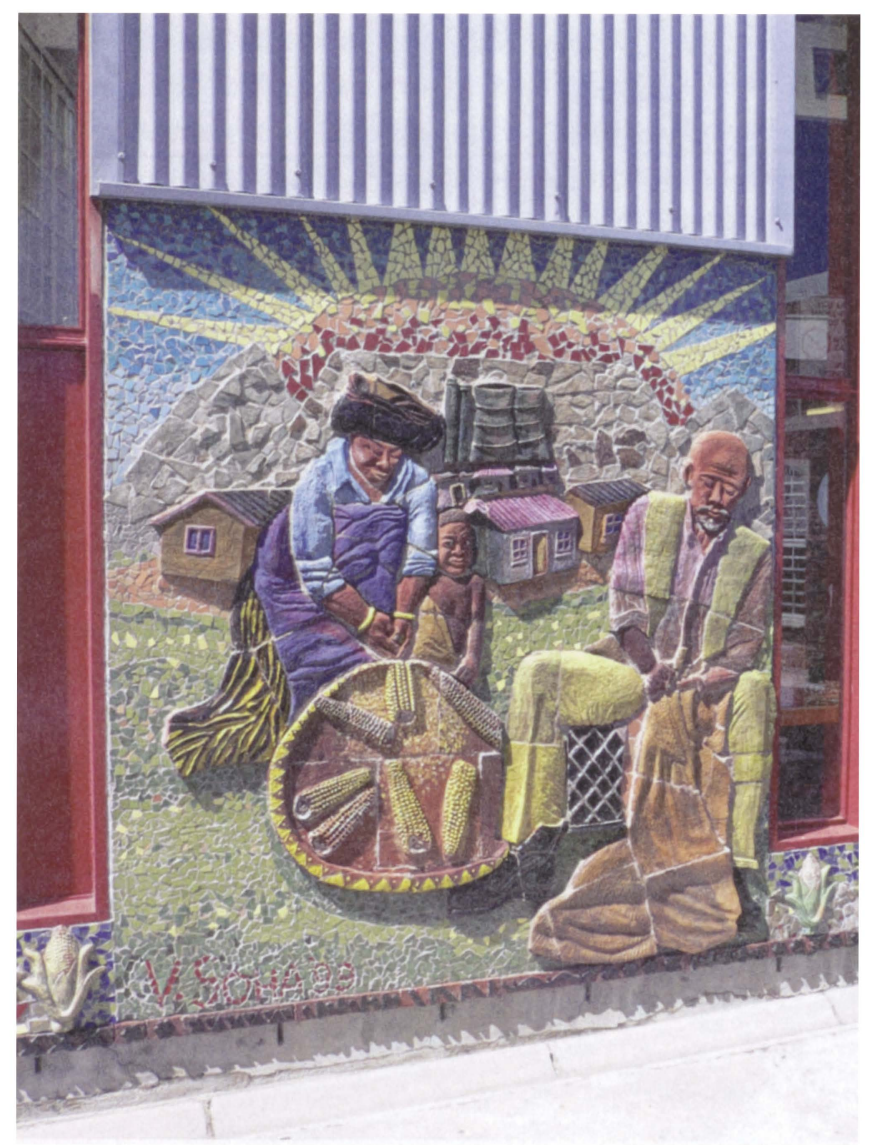

Figure 8: Ceramic mosaics on the "garden wall" and in the semi-public forecourt (photographs by the author)

As part of CS Studio Architects' usual design strategy, the architects wanted community involvement to be central to the realization of this project ${ }^{20}$. An important aspect in this respect was the design and implementation by local artists of ceramic mosaics which can be found in different parts of the building. According to Smuts, these mosaics project the memory of the community and tell the story of Langa, the modernization of the townships, the importance of music and dance and the different arts and crafts, again stressing the S'Thebe metaphor (Figure $7 \& 8$ ). The architects thus use a highly meta-

Smuts puts great emphasis on community participation in the process of developing a project, from conception to realization and maintenance. Another project where this was particularly important is the Wesbank primary school in Cape Town, where, from inception, meetings were organized with the local community to identify their expectations and needs. For the Guga S'Thebe project, initially, everyone living in Langa was invited to contribute to the identification of the project. Then the project was judged by smaller groups using drawings and models. Once construction started, members of the community were invited to become part of the execution team. Finally, the center is also managed by members of the community, who organize township tours as part of the Langa experience. 
phorical architectural vocabulary, explicitly referring to an ideal South African culture by selecting aspects from the memory and (spatial) nature of Langa. References to the Guga $S$ 'Thebe metaphor and the rondawel, the imitation of the traditional use of vivid colors in Langa, and the direct representation of the history and customs of the community, all contribute to an unequivocal architectural language which does not require an active process of interpretation by its users. As such, the building leaves no doubt about what it represents and validates, and as such generates a very particular kind of monumentality, intended for a township context. Whereas in the Browns Farm case, the architects expected local people to build - literally and figuratively - a community and a (Rainbow) identity through the steady appropriation of the concrete structure, the Guga S'Thebe design is rather meant to be appropriated and charged with meaning via the assimilation of a very clear, predefined and 'finished' image which aims to function as a mirror for the community.

Architecture \& social change: undetermined development versus over-determined identity.

Although using very different architectural tools, Smuts' and du Toit, Perrin \& Theron's projects both in their proper way explore how architecture could potentially participate in the process of social change that incites the quest for an 'authentic' contemporary South African identity. In her book entitled Building change. Architecture, politics and cultural agency, Lisa Findley elaborates on this topic by investigating "the shifting relationships among power, space and architecture in a world where a number of subjected people are reasserting their political and cultural agency" (Findley, 2005: i). By discussing four different case-studies, she argues that "while [architectural] practice cannot provoke political change per se, it has real power to engage in and enhance social change through its participation in the actual making of physical space". In all four projects, architecture gains considerable leverage to participate in social change, convincing readers that the intervention is in some way meaningful (which is not being called into question here). However, the case-studies under scrutiny in this paper illustrate that even within one very particular context, this participation can take many different forms and sometimes takes place in unexpected ways. Although both projects share a concern for referring to Rainbow Nation philosophy, they each represent opposite ends of the spectrum in which contemporary architects in Cape Town are operating and positioning themselves: on the one end in Browns Farm a strategy that could be called "undetermined development", on the other end in Langa a design approach we could refer to as "over-determined identity". Inevitably, then, the question arises as to the extent to which architecture can in fact participate in a discourse on social transformation and identity (re)construction; how much responsibility lies with architecture to, in Findley's words "manifest renewed cultural agency by making it spatial, material, present and, in that sense, undeniable" (Findley, 2005: xiii); and what it might be about architecture that generates this potential. To make a meaningful statement about this, we need to return to the autonomy of the architecture an sich. 
Following the DPP philosophy, du Toit, Perrin \& Theron explicitly denominate the project as 'social urban infrastructure' - realized with minimal investment from the CoCT - that would in time be developed by the community and thus only slowly become an actual 'building'. It is a kind of concrete foundation, unequivocally designed for amenity, driven by usefulness. Furthermore, it makes no statement about historical or symbolic references, nor does it make any explicit effort (except perhaps by its scale) to inscribe itself in the spatiality of the township. The emphasis on functionality is further reinforced by the predominant use of concrete, chosen to generate a robust appearance. This market project seems to be a good example of what Hannah le Roux called a 'holding back strategy' "where the architect defers design by allowing users to construct, at least in part, spaces of significant identity and value through their own suggestion or physical involvement. The idea of the open or unfinished project is central." (le Roux, 1998: F9) Meanwhile, it could be argued that the building does very clearly make a statement about architectural expression. Although the designers did not strive for monumental representation to frame public activity, they proposed a strong formal gesture in response to the need for a 'dignified public space'. Du Toit, Perrin \& Theron introduce the urban gallery or colonnade, a common typology to demarcate public space in the West. Imagining the first level with dwellings on top of public institutions and shops, this analogy becomes even stronger. The concrete framework of roughly 4 by 4 by 3.5 meters probably results from structural concerns, but at the same time these dimensions generate a building on a human scale, as well as on the scale of the environment. Moreover, the robust concrete framework renders a very rigorous and orderly aspect to the building, further emphasized by the tight sequence of wooden trusses in the horizontal plane.

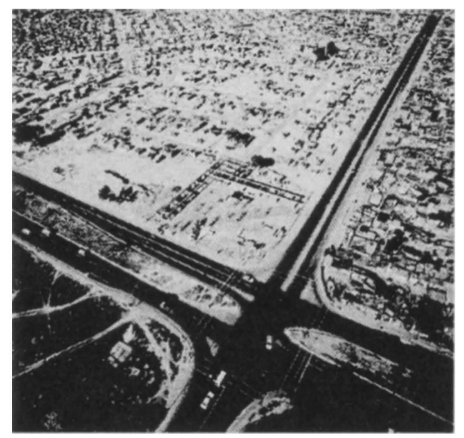

Figure g: Birds eye perspective Browns Farm market structure (photograph: courtesy of the architect)

Hence, although it is presented as social infrastructure, there is more to this apparently modest structural operation than the architectural discourse leads us to believe. Figure $g$ illustrates that the shape of the building and the way the grid delineates this new 'place' are not gratuit. This is not self-evident, as up until the abolition of apartheid, there was no official vision of how a sense of identity could be generated through public space and the built environment in the townships. The design strongly relies on the rhythm of 
the structure, its potential to define public space, and the adequacy of the building concept vis-d $d$-vis the context, to generate a sense of dignity, even a specific kind of monumental quality which does not necessarily have to do with size, but rather with the intensity of expression and presence on the site. By thus defining a kind of center, the carefully designed grid structure, handed to the community by the architects, seeks to be appropriated (and transformed) by its users in order to stimulate a sense of group identity without necessarily losing its essence as an architectural gesture.

Carefully staged photographs in architecture magazines, national as well as international ${ }^{21}$, show the completed building as a promise of development. However, in contrast to this picture of potential, the Browns Farm project led an arduous and turbulent existence before recently becoming occupied by a mortician, a doctor, a workshop for a car mechanic, and a chemist. As Matthew Barac states in his review of this project, the play between space and society is a fragile equilibrium which the authorities are often illplaced to supervise (Barac, 2007: 36-39) ${ }^{22}$. Indeed, as there was no policy in the city that could support lease or transfer of property - enabling people of limited financial strength to become owner of their professional territory - the city built walls between the portico's and decided to rent the individual modules. However, as this is financially undesirable, the local community initially showed very little interest in this solution and consequently, most of the structure fell into disuse and for a long time remained in a dilapidated state (Figure 10). The knuckle was used as a dump, though very recently it has been cleaned up, and the most important public activity on the square remains a car wash, which in fact functions surprisingly well. Other DPP initiatives such as the public space project around Philippi station - designed by the same architects and based on a similar concept of flexibility, gradual development and appropriation - have been relatively successful in demarcating a meaningful public space and generating public activity, albeit often in unexpected ways and not necessarily grafted onto the 'formal' structure introduced by the DPP program (Figure II) ${ }^{23}$. In contrast to such unexpected uses, appropriation of the building in Browns Farm is taking place in a relatively restrained and tentative way (Figure I2 \& 13 ).

21 The Architectural Review: volume CCXXI no 1324, June 2007, p.36-39. Digest of South African Architecture, 2003, p.56.

22 Stephen Boshoff and Barbara Southworth indeed indicate in their 2003 programme review report of the DPP program that "Each of the municipal functions seeks to maximise its own operation and attempts to claim exclusive territory, or relieve itself of responsibility... [Public space] is planned, managed and maintained by a host of uncoordinated functions and levels of government. As a result public spending in this area is not well used and the confusion around roles and responsibilities within local government makes it very difficult for community groupings to engage with local authorities around using these spaces more effectively."

23 "... the unexpected, but positive, uses that the completed projects have accommodated demonstrate the value of designing flexibility into public spaces... children play on tables and seating originally intended for traders in one project, and in another, low walls provided for seating have become display spaces for itinerant traders. Bands use the steps of one community centre for concerts and, where previously there had been a fence, steps to a community hall now accommodate regional choir competitions and group photograph." (Southworth, 2003: 119-133). 


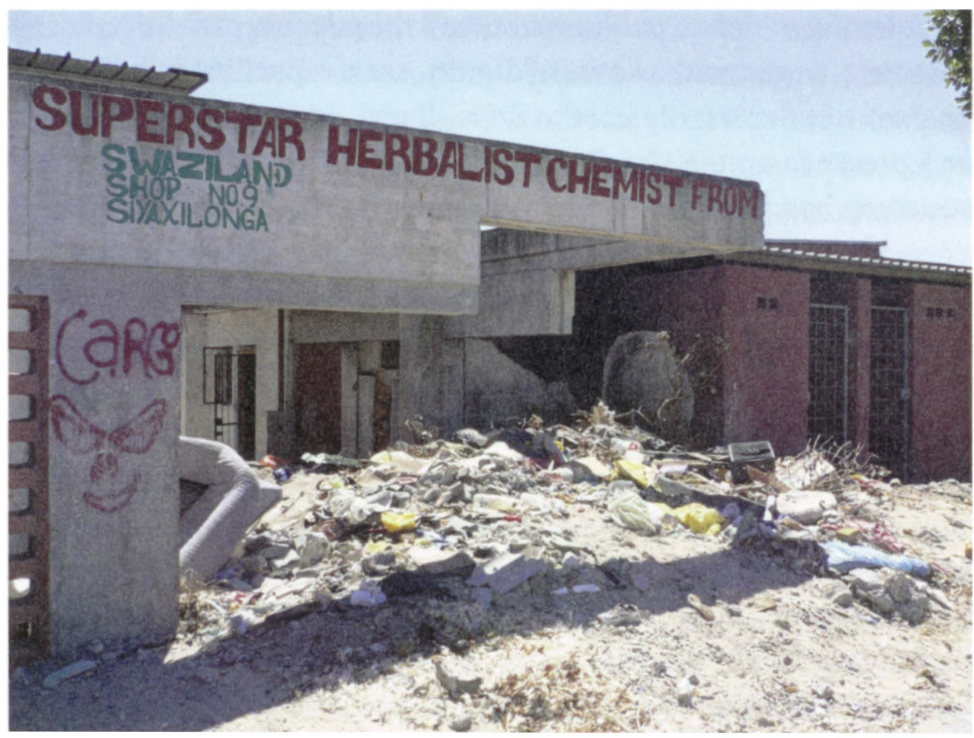

Figure 10: Knuckle of the structure intended as public living room (photograph by the author)

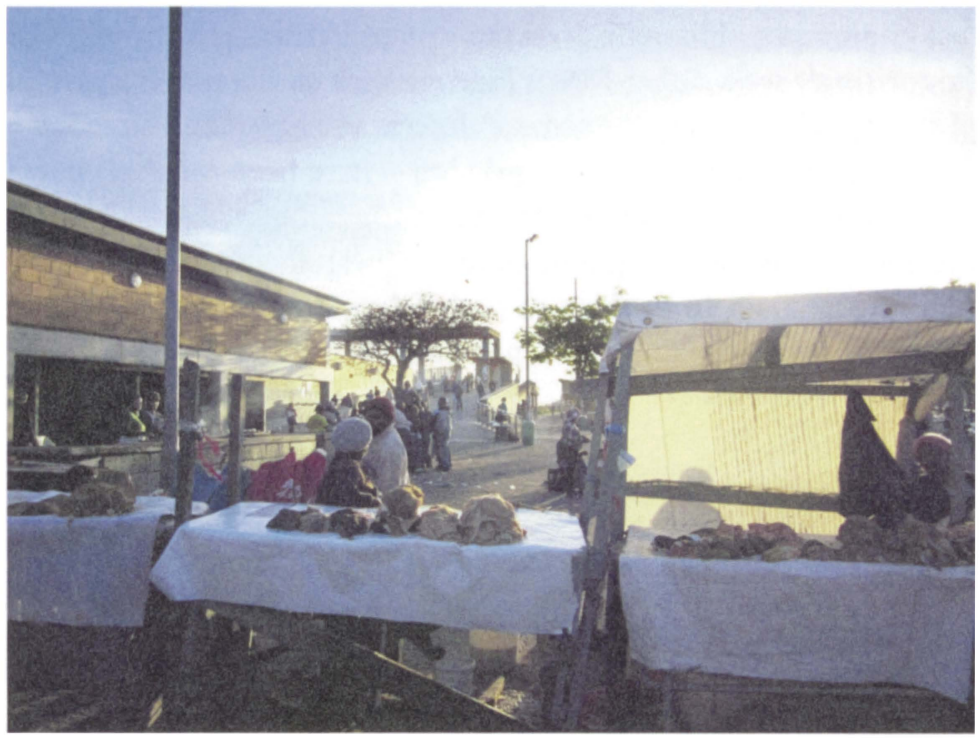

Figure 11: Philippi Station DPP project; also by Du Toit \& Perrin Ass. The colonnade has contributed to the arising of a clearly demarcated, dense node of activity around the station. Informal activities like street trading, children playing and youngsters gathering have capitalized on this public presence and appropriated the 'infrastructural' equipment of the public plaza.

(photograph by Ana Michelena, courtesy of the photographer) 


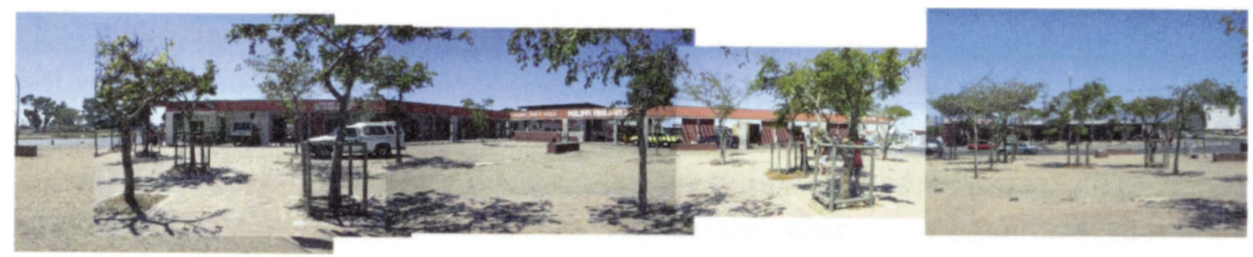

Figure 12: Collage showing the tentative appropriation of the Browns Farm building in 2010 (photographs and manipulation by the author)

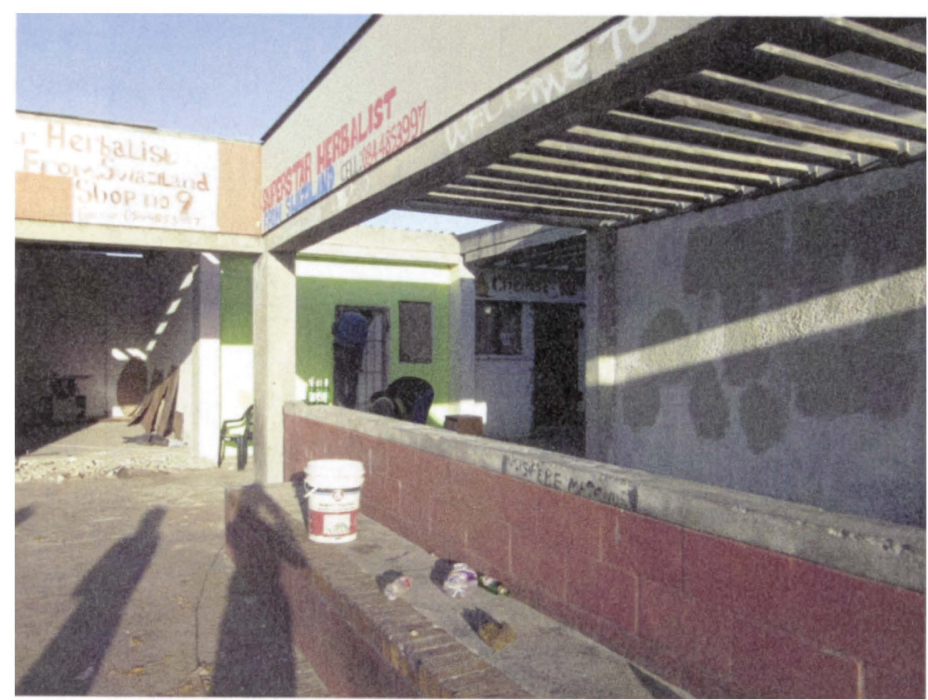

Figure 13: Gradual development of the units around the knuckle (September 2011) (photograph by Ana Michelena, courtesy of the photographer)

Guga S'Thebe, on the other hand, has since its completion in 1999 enjoyed a reasonable level of success in terms of achieving the promoters' and designers' initial intentions, having become an important tourist attraction ${ }^{24}$ in the Cape Town region. The building is very well maintained and benefits from a well functioning organizational board. In part this may well be due to the intensive involvement of the community throughout the different stages of realization, empowering them to a certain degree in the positive development of their built environment. In spatial terms however, this building comes across as a metaphorical white elephant, standing out sharply within the poor township tissue. This effect is further enhanced by the man-high garden wall which, metaphorically, had to evoke township spatiality, but in fact reinforces the sense of seclusion as it was at

24 Supposedly this is to an important degree due to the fact that the center can offer a safe township tour, followed by a visit to the center where township souvenirs can be bought: mostly small objects crafted by members of the Langa community. 
the same time designed to make full enclosure of the building (an absolute necessity in the townships) possible. As a result, the intended ambiguity between inside and outside space is partially lost because it has had to give way to security issues. Hence, despite the abundance of both direct and indirect references to the typical history and spatiality of Langa, the S'Thebe (platter) metaphor seems to succeed primarily in terms of its social ambitions, bringing people from different generations and backgrounds in the community together to practice and transmit local arts and crafts knowledge. In spatial terms, however, the project could be read as a projection of a future condition, or material representation of hope and expectation.

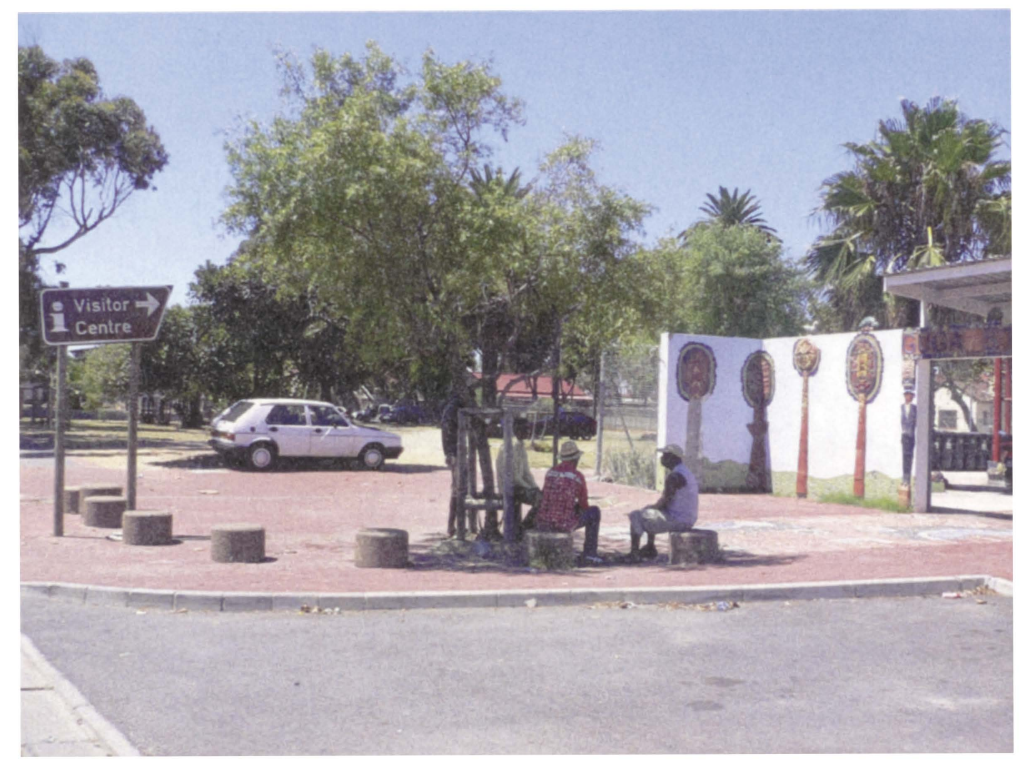

Figure 14: Signage on the street side of Guga's Thebe indicating the main function of the center (photograph by the author)

Like du Toit, Perrin \& Theron, but much more explicitly, Smuts is strongly committed to the quest for a particular architectural vocabulary to shape a typically South African architectural identity. However, the imposition of the Guga S'Thebe image onto the community does not allow for a very sensitive and nuanced process of appropriation and identity formation. As meaning is crudely filtered and unequivocally translated into built form to be the ultimate materialization of Rainbow Nation philosophy, there is little space is left for critically questioning the architect's selection of meaningful content. The project could thus potentially become the ultimate setting for tourist recreation (a process which already seems to be en route, as can be seen in Figure 14, showing a sign indicating that the building is first and foremost a 'visitor center'), detached from its original context and raison d'être. When addressing the problematic notion of 'community' in architectural debates, Murray points to the danger of such crude translations of a supposed 'African culture' into built form: "...community architects and planners by 
virtue of their outsider status, also bought into a series of at best misguided and at worst patronising, ideas about African space-making and practices. These are the crudely translated curvilinear forms and bright colours to which Judin and Vladislavic allude" (Murray, 2007: 43-66). The author clearly makes a strong case for the problematization of the issue of the '(South) Africanization' of international currents in the sphere of architecture. Such an architecture which constructs a tangible representation of (a collection of ) images and abstract concepts indeed seems to hold the risk of losing touch with the much more complex original context from which the building was created as well as from contemporary reality. Indeed, as Wilson (200I) explains, as meanings and memory become fixed to an object or a building, a process of 'freezing of history' takes place whereby the architecture is gradually hollowed out, becoming a symbol or, at worst, a three-dimensional billboard.

\section{Conclusion}

By attempting to detach ourselves from the authoritative discourse of social change and identity formation, we are confronted with the question of autonomy of the architecture an sich, as well as the concept of 'openness' therein. Indeed, as Findley states "just as architecture fixes materials in time and space, it also fixes meaning. ... When ongoing political and cultural tensions are part of what must be translated in a building through architecture ... a critical problem arises: the architect is responding to a moment in the evolution of dynamic relationships between groups of people with different visions of what the future is to be ... While the change itself is predictable, what the change will entail or how soon it will be needed is not." Clearly architecture has the potential to impose certain 'rules of play' to the appropriation of buildings and their potential to generate a sense of (group) identity, thus evoking the strong connection between architecture and politics. However these case-studies confront us with the fact that whatever choice is made to over- or underdetermine its development, this is never fully in the hands of the designers. Moreover, in the Browns Farm market, and by extension all DPP projects, the potential of the architecture an sich seems to be just as big an issue as its role in identity formation and social change is. Although not always equally successful, it is interesting that the DPP initiative provides space for architectural experiment by focusing on design principles and tools rather than on architectural form per se. Thus, the building's openness seems to lay not so much in the free parameters of its development, as in the autonomy of the architectural gesture. The architecture of Guga S'Thebe has, on the other hand, a very close affinity with the discussion on memory and identity and by extension social change. Therefore it potentially faces the risk of gradually becoming a building that only passively contributes to the image of a unified South Africa, where the architecture is slowly hollowed out and meaning becomes increasingly symbolic.

In conclusion, these cases illustrate that it is not so much the explicit relationship in which architecture enters with concepts such as social change and identity formation, as it is the architectural gesture itself, which determines how a building operates and behaves in a particular context such as Cape Town's townships. Indeed, despite this im- 
portant relationship - always at the center of debates about memory projects - this study illustrates that the discipline of architecture possesses a certain autonomy an sich which allows it to transcend intangible discussions about meaning and identity, by playing out the potential of its basic tools. Ultimately, the most salient point is the fact that this debate on public space is, and continues to be, held. The fact that it leads to such diverging positions, be they successful or otherwise, seems promising in itself.

\section{Acknowledgements}

Writing this article following the work I did for my master thesis would have been unimaginable without the unstinting support of my promotor Prof. Johan Lagae. I would also like to thank Prof. Iain Low, my local co-promotor in Cape Town. By including me in his Research Methods Class, he has given me an opportunity to understand architecture in a very different context. Our intense discussions on contemporary South African architecture have been instrumental for writing this article. Furthermore, I am grateful to the Flemish travel grants programme of VIIR-UOS for financially supporting the fieldwork for this article. Lastly I owe my gratitude to Jacqui Perrin and Carin Smuts, who kindly agreed to discuss their projects with me and provided me with interesting material. The author is solely responsible for any remaining errors.

\section{References}

Anderson, Benedict (1983). Imagined Communities. London: Verso.

Barac, Matthew (June 2007). Great Expectations. The Architectural Review, vol. CCXXI (no 1324): pp. 36-39.

Barton, Craig E. (200I). Sites of memory - perspectives on architecture and race. New York: Princeton Architectural Press.

Boshoff, Stephen \& Southworth, Barbara (2003). The City of Cape Town's Ukuntu Plaza Dignified Places Programme Review Report.

http://www.macalester.edu/courses/geog26r/cape_town_and_beyond/images/

dignified\%2oplaces\%2oprog.pdf.

Bremner, Lindsay (2007). Memory, Nation Building and the Post-apartheid city. In: Hall, Martin et al. (eds.), Desire Lines - Space, memory and identity in the post-apartheid city, pp. 85-103. New York: Routledge.

Coombes, Annie E. (2003) History after apartheid: Visual culture and public memory in a democratic South Africa. New York: Duke University Press.

Distiller, Natasha \& Steyn, Melissa (eds.) (2004). Under Construction: 'Race' and Identity in South Africa Today. Sandton: Heinemann.

Doxtader, Erik \& Villa-Vicencio, Charles (eds.) (2004). To Repair the Irreparable. Reparation and Reconstruction in South Africa. Claremont: David Philip Publishers.

Evans, Jessica \& Boswell, David (eds.) (1999). Representing the nation: a reader: histories, heritage and museums. London: Routledge.

Findley, Lisa (2005). Building change. Architecture, politics and cultural agency. London: Routledge.

Graham, Brian \& Howard, Peter (eds.) (2008) The Ashgate research companion to Heritage and Identity. Hampshire: Ashgate Publishing Company.

Kearney, Brian \& Marschall, Sabine (2000). Opportunities for relevance: architecture in the new South Africa. Pretoria: UNISA Press. 
Kezer, Zeynep (2009). An imaginable community: the material culture of nation-building in early republican Turkey. Environment and Planning D: Society and Space, vol.27: pp. 508-530.

Leach, Neil (2005). Belonging: Towards a Theory of Identification with Place. In: Hillier, Jean \& Rooksby, Emma (eds.), Habitus: a sense of place (second edition), pp. 297-308. Aldershot: Ashgate Publishing.

Lefebvre, Henri (199I). The Production of Space. Oxford: Blackwell Publishing Ltd. Translated from the original Production de l'Espace (1974). Paris: Editions Anthropos by Donald Nicholson-Smith.

Le Roux, Hannah (1998). Undisciplined practice: Architecture in the context of freedom. In: Judin, Hilton \& Vladislavić, Ivan (eds.), Blank_Architecture, apartheid and after, pp. "F9". Rotterdam: NAi publishers.

Lipstadt, Helène (1999). Review: Realms of Memory: The Construction of the French Past by Pierre Nora. Journal of the Society of Architectural Historians, vol.58 (no 2): pp. 243-5.

Lu, Duanfang (20II). Third World Modernism: Architecture, Development and Identity. Oxon: Routledge.

Marschall, Sabine (2005). Reordering the Past: Monuments and Architectural Heritage in Post-Apartheid South Africa. In: Repenser les limites : l'architecture d̀ travers l'espace, le temps et les disciplines. http://inha.revues.org/r69I. INHA Paris August 3I - September 42005.

Murray, Noëleen (2007). Remaking Modernism: South African Architecture In and Out of Time. In: Hall, Martin et.al. (eds.), Desire Lines - Space, memory and identity in the post-apartheid city, pp. 43-66. New York: Routledge.

Southworth, Barbara (1999). City Squares in Cape Town's Townships - Public Space as an Instrument of Urban Transformation: The Origins, Objectives and Implementation of the City of Cape Town's Dignified Places Programme, http://ndp.treasury.gov.za.

Southworth, Barbara (2003). Urban design in action: the City of Cape Town's Dignified Places Programme - implementation of new public spaces towards integration and urban regeneration in South Africa. Urban Design International, vol. 8, pp. Irg-133.

Southworth, Barbara (2005). Public Space in Developing Countries: The City of Cape Town's Dignified Places Programme. Lotus International, vol. 124: pp. 4-Ir.

Vale, Lawrence (1992). Architecture, power and national identity. New Haven: Yale University Press.

Wilson, Mabel O. (2001). Between rooms 307. Spaces of Memory at the National Civil Rights Museum. In Barton, Craig E. Sites of memory - perspectives on architecture and race, Princeton Architectural Press, New York.

Zegeye, Abebe (ed.) (200I). Social Identities in the New South Africa. After Apartheid - Volume One, Cape Town: Kwela Books.

\section{Interviews February 2010}

Carin Smuts / CS Studio Architects

Jacqueline Perrin / du Toit \& Perrin Associates 